\title{
Observation and Modeling of the January 2009 West Papua, Indonesia Tsunami
}

\author{
Yushiro Fujit, ${ }^{1}$ Kenji SAtake, $^{2}$ and Yuji Nishimae ${ }^{3}$
}

\begin{abstract}
We modeled a tsunami from the West Papua, Indonesia earthquakes on January 3, $2009\left(M_{\mathrm{w}}=7.7\right)$. After the first earthquake, tsunami alerts were issued in Indonesia and Japan. The tsunami was recorded at many stations located in and around the Pacific Ocean. In particular, at Kushimoto on Kii Peninsula, the maximum amplitude was $43 \mathrm{~cm}$, larger than that at Manokwari on New Guinea Island, near the epicenter. The tsunami was recorded on near-shore wave gauges, offshore GPS sensors and deep-sea bottom pressure sensors. We have collected more than 150 records and used 72 stations' data with clear tsunami signals for the tsunami source modeling. We assumed two fault models (single fault and five subfaults) which are located to cover the aftershock area. The estimated average slip on the single fault model $(80 \times 40 \mathrm{~km})$ is $0.64 \mathrm{~m}$, which yields a seismic moment of $1.02 \times 10^{20} \mathrm{Nm}$ $\left(M_{\mathrm{w}}=7.3\right)$. The observed tsunami waveforms at most stations are well explained by this model.
\end{abstract}

Key words: West Papua, Indonesia 2009 earthquake, tide gauge, wave gauge, GPS buoy, ocean bottom tsunami sensor, tsunami simulation.

\section{Introduction}

A large earthquake occurred on the north coast of Doberai Peninsula, West Papua, Indonesia $\left(0.408^{\circ} \mathrm{S}\right.$, $132.886^{\circ} \mathrm{E}, M_{\mathrm{w}}=7.7$ at $19: 43: 50 \mathrm{UTC}$ according to USGS) on January 3, 2009. This earthquake was followed by the second event $\left(0.707^{\circ} \mathrm{S}, 133.361^{\circ} \mathrm{E}\right.$, $M_{\mathrm{w}}=7.4$ at, 22:33:40 UTC, according to USGS) $3 \mathrm{~h}$ later at about $60 \mathrm{~km}$ southeast. Focal mechanisms of thrust type by USGS's CMT solutions and the shallow depth of about $20 \mathrm{~km}$ indicate that these events

1 Building Research Institute (BRI), International Institute of Seismology and Earthquake Engineering (IISEE), 1-3 Tachihara, Tsukuba, Ibaraki 305-0802, Japan. E-mail: fujii@kenken.go.jp

2 Earthquake Research Institute (ERI), University of Tokyo, 1-1-1 Yayoi, Bunkyo-ku, Tokyo 113-0032, Japan.

3 Japan Meteorological Agency (JMA), 1-3-4 Otemachi, Chiyoda-ku, Tokyo 100-8122, Japan. occurred on the plate boundary along the Manokwari Trench (e.g. OкаL, 1999) where the Pacific Plate is subducting beneath the Australian Plate (Fig. 1).

After the first event, Meteorological, Climatological and Geophysical Agency, Indonesia (BMKG) issued an alert for a local tsunami potential near the source region. According to the field survey of the coastal area, northern West Papua, near the sources (Munari et al., 2009), the run-up heights were up to $1.97 \mathrm{~m}$. The tsunami did not cause much damage to houses or fisheries facilities, and there were no casualties.

Far from the West Papua coast, the Japan Meteorological Agency (JMA) issued a Tsunami Advisory to the Izu-Bonin Islands, the southwestern coasts of Honshu and Shikoku Islands facing to Pacific Ocean, eastern coast of Kyushu Island, and Satsunan Islands (Fig. 2). The observed tsunamis at tide gauges along the Japanese coast range from a few to several tens of centimeters. The maximum tsunami amplitude of $43 \mathrm{~cm}$ was recorded at Kushimoto.

Around New Guinea Island, many earthquakes have occurred in the past. The earthquakes in 1996, 1998, September and October 2002, which generated tsunamis are noted with their labels in Fig. 1. The 1996, 2002 September and October tsunamis reached coasts in Japan, and were observed at some tide gauges. For the 1996 and September 2002 events, maximum tsunami heights of $1.04 \mathrm{~m}$ at Chichijima and $0.20 \mathrm{~m}$ at Naze were recorded, respectively (JMA, 2002, 2009).

The 2009 tsunamis were recorded not only at highly dense coastal tide gauges and near shore wave gauges but also at GPS buoys and ocean bottom tsunami sensors (OBTS) recently installed. For example, JMA's OBTS system in Tonankai was just started in November 2008 to monitor oceanographic phenomena such as tides, wind waves or tsunamis. 
In this paper, we describe the observed tsunami heights and waveforms, and model the tsunami to estimate the tsunami source using those data.

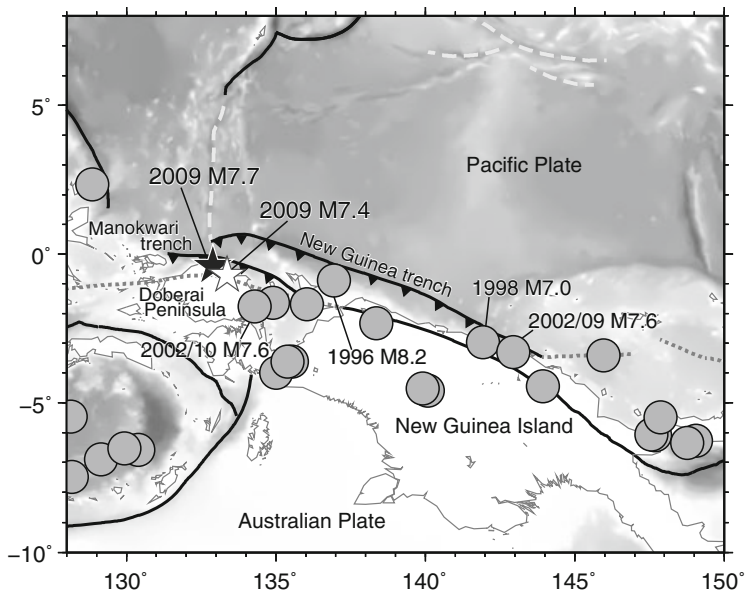

Figure 1

Epicenters of the January 2009 West Papua, Indonesia earthquakes (black star first event, white star second event). Gray circles indicate the previous earthquakes whose magnitudes are greater than seven, of which the events with labels are tsunamigenic earthquakes

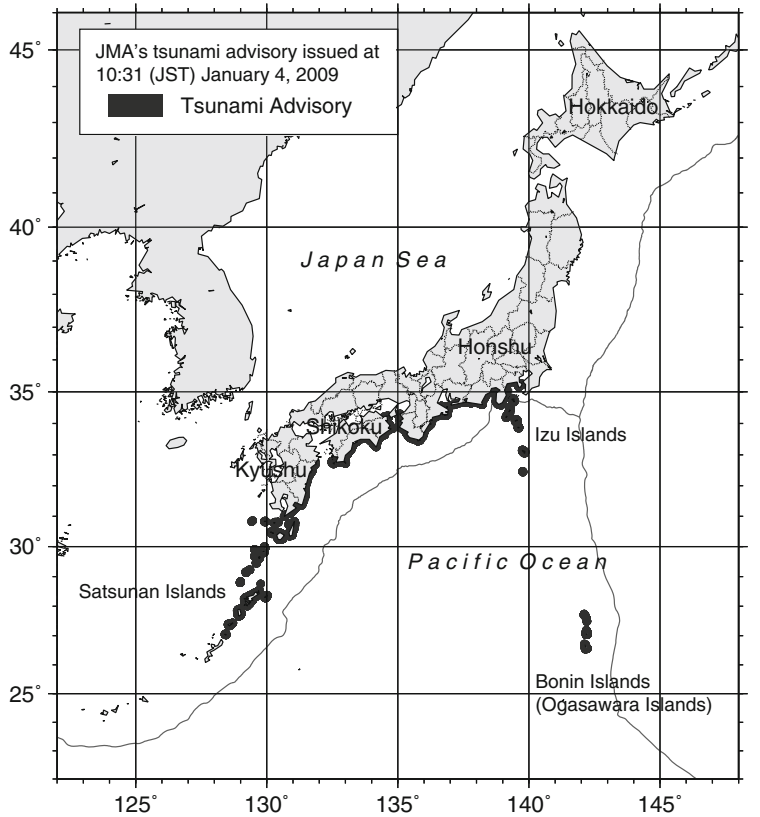

Figure 2

Coastal areas of Japan, where tsunami advisories were issued by JMA for the January 2009 West Papua, Indonesia earthquakes

\section{Observed Tsunamis}

Tsunamis from the 2009 West Papua, Indonesia earthquakes were recorded on many coastal tide gauges in and around the Pacific Ocean (Fig. 3), as well as near-shore wave gauges, off-shore GPS buoys, and cabled OBTS (pressure gauges) off the Japanese coasts (Fig. 4). We have collected 105 tide gauge waveforms including tsunami signals from Indonesia's National Coordination Agency for Surveys and Mapping (BAKOSURTANAL), JMA, Japan Coastal Guard (JCG), Japan's Geographical Survey Institute (GSI), and USA's West Coast/Alaska Tsunami Warning Center (WCATWC). The tsunamis were also recorded at 29 near-shore wave gauges and eight offshore GPS buoys operated by Japan's Nationwide Ocean Wave information network for Ports and HArbourS (NOWPHAS). Tsunami sensors installed on the ocean bottom by JMA and the Japan Agency for Marine-Earth Science and Technology (JAMSTEC), 11 sensors in total (Boso 1, one of JMA's OBTS, malfunctioned), successfully recorded tsunami signals as well as seismic signals. Among these data, we selected 50 tide gauges, 10 wave gauges, 3 GPS buoys and 9 OBTS, which clearly recorded tsunami signals to be used for tsunami modeling. The locations of these selected stations, 72 in total, are listed in Table 1.

Figures $3 b$ and $4 b$ show the maximum tsunami heights (positive values of zero-to-peak in tsunami waveforms after the data processing which will be described later) at the observation stations. The tsunami heights are larger along the Izu-Bonin ridge system and the southern coasts of Japan, because of the waveguide effect (trapped wave energy in shallow ridge region) as pointed out by SATAKE and KANAMORI (1991) and SATAKE et al. (1992).

The tide gauge, wave gauge, GPS buoy and OBTS records usually include low frequency ocean tides and high frequency waves such as seismic waves or wind waves. We filter these records to retrieve the tsunami signals in the following way. First, we approximate the tidal component as a polynomial function, and remove the tides from the original records. Then, we apply a moving average with a box-car function which has a band width of three sampling points to reduce the high frequency noises. Figure 5 shows the processed records as examples of 
a

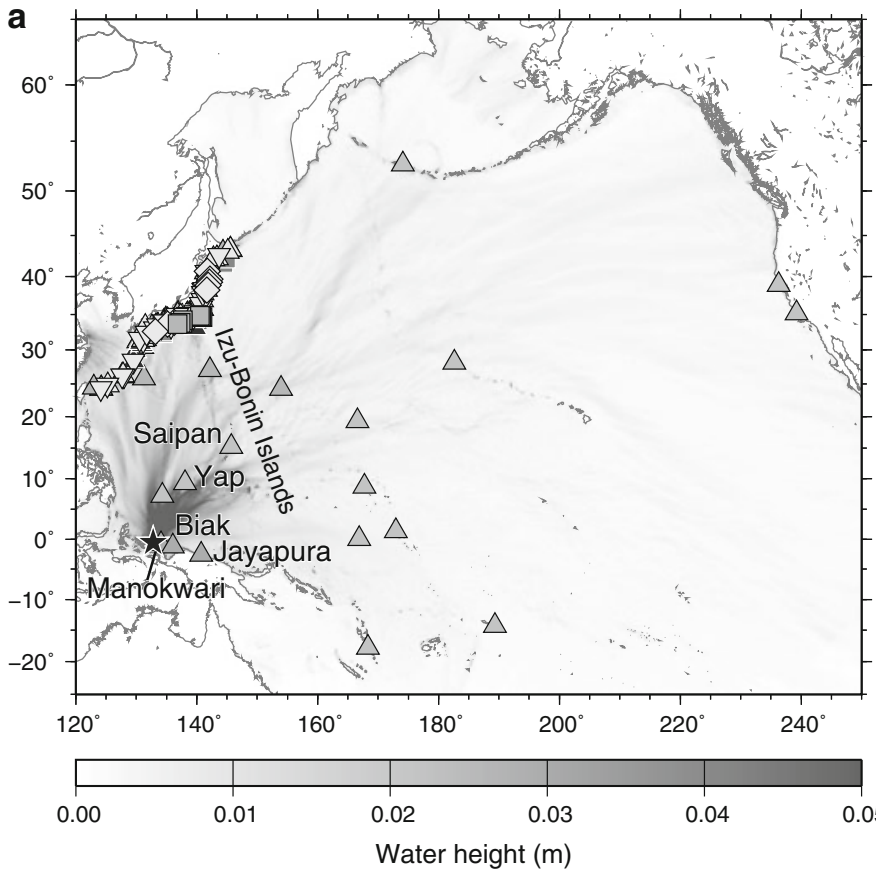

$\triangle$ BAKOSURTANAL

$\triangle$ WCATWC

$\triangle \mathrm{JMA}$

$\triangle \mathrm{JCG}$

$\triangle \mathrm{GSI}$

JAMSTEC

(OBTS)

JMA

(OBTS)

$\nabla$ NAWPHAS

(WG)

NAWPHAS

(GPS)

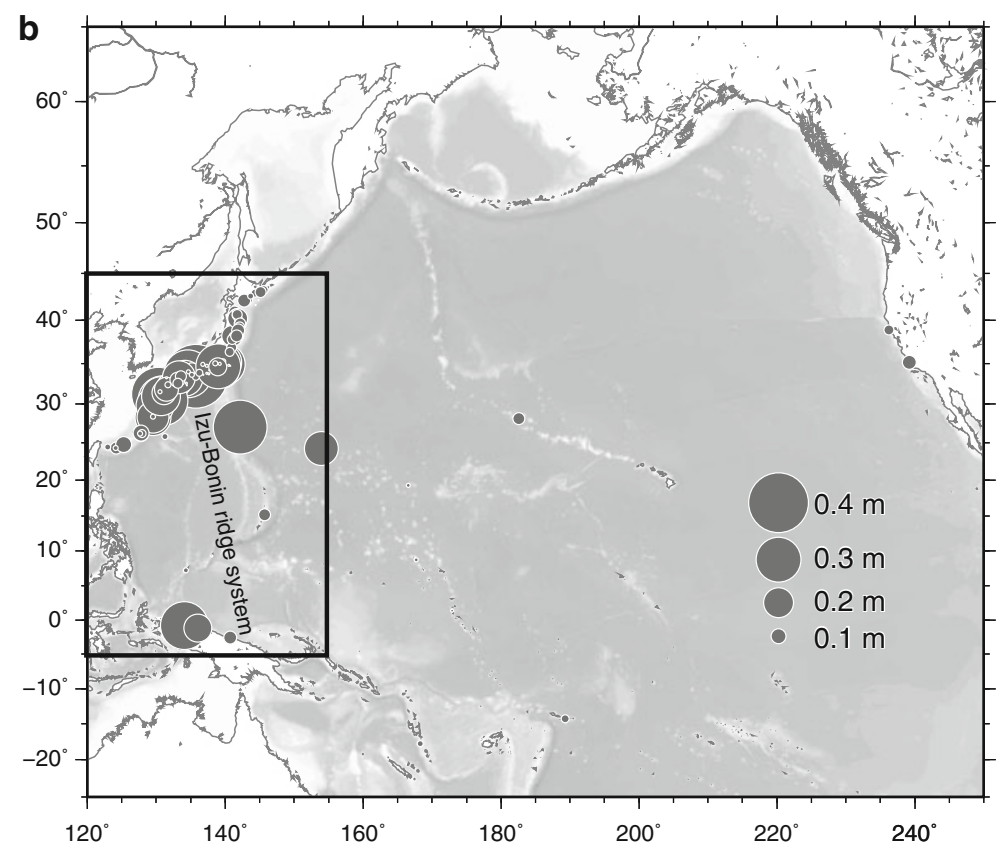

Figure 3

a Locations of stations which recorded the 2009 West Papua, Indonesia tsunami, overlaid on the distribution of the simulated maximum tsunami height. Triangles, squares, inverted triangles and diamonds indicate the tide gauges, ocean bottom tsunami sensors (OBTS), wave gauges (WG) and GPS buoys, respectively. Epicenter of the first event (black star) is also shown. b Maximum heights (absolute values of zero-to-peak or zero-to-trough) of the observed tsunamis. Rectangular shows the computation area for tsunami simulations

a wave gauge at Shionomisaki, a GPS buoy off Mie Owase, and an OBTS of MPG2 off Shikoku (see Fig. 4a for the locations).
The observed tsunami waveforms indicate that the tsunami amplitudes range from a few to $40 \mathrm{~cm}$ at the tide gauges, a few to $10 \mathrm{~cm}$ at the wave gauges, up to 

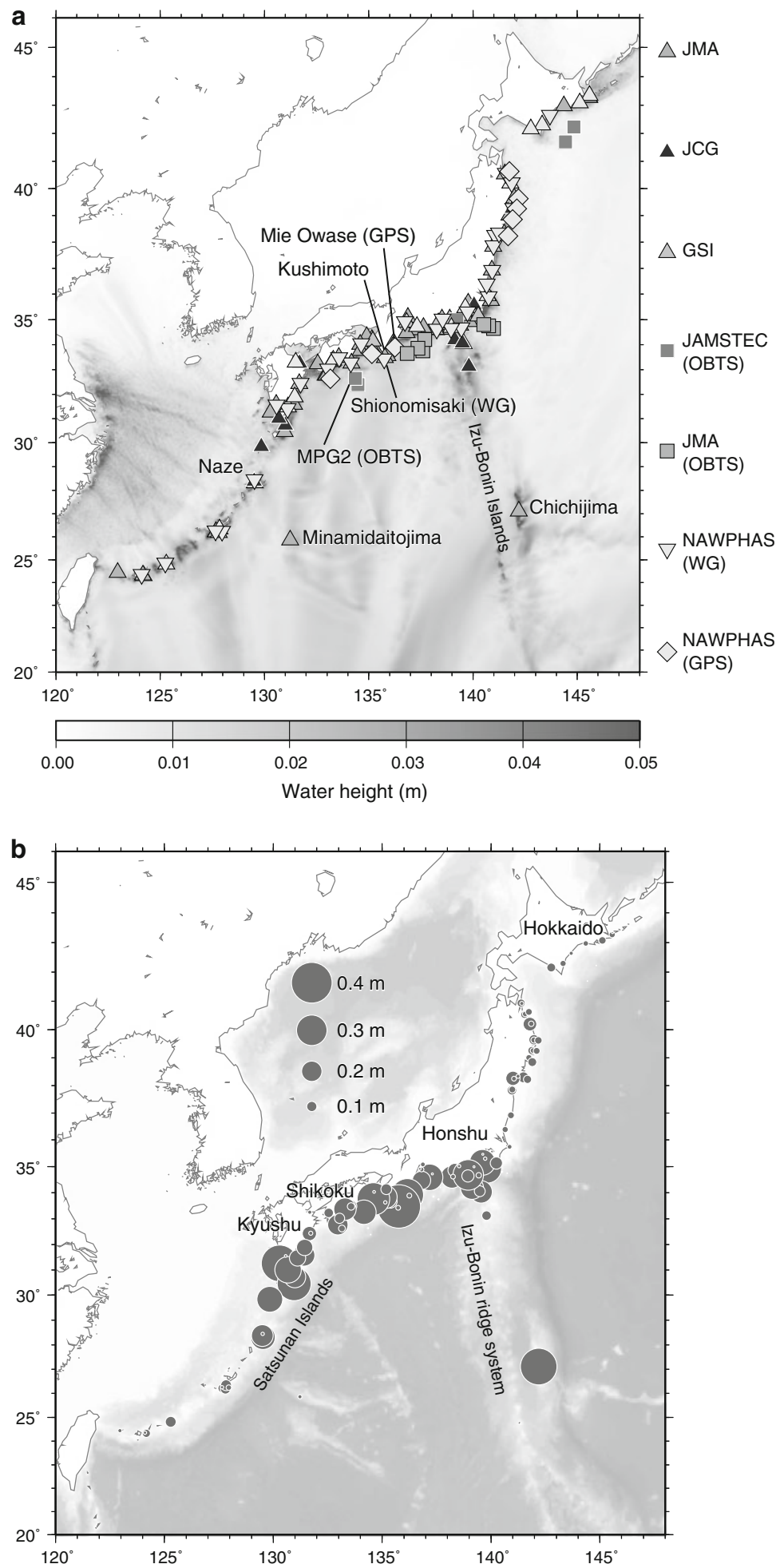

Figure 4

a Same as Fig. 3a, but for the region around Japan. The sources of the 2009 West Papua, Indonesia earthquakes are far south of this map (see Fig. 3a). b Same as Fig. 2b, but for the region around Japan 
Table 1

List of tide gauges, wave gauges, GPS buoys and OBTS

\begin{tabular}{|c|c|c|c|c|c|c|}
\hline Station* & Latitude (deg:min:s) & Longitude (deg:min:s) & Water depth (m) & Record sampling & MTH $(\mathrm{m})^{* *}$ & Agencies*** \\
\hline Manokwari & $0: 51: 25 \mathrm{~S}$ & 134:04:38E & & $1 \mathrm{~min}$ & 0.32 & BAKO \\
\hline Biak & $1: 10: 40 \mathrm{~S}$ & 136:03:21E & & $3 \mathrm{~min}$ & 0.19 & BAKO \\
\hline Jayapura & $2: 32: 42 S$ & $140: 42: 46 \mathrm{E}$ & & $1 \mathrm{~min}$ & 0.088 & BAKO \\
\hline Yap & $9: 18: 18 \mathrm{~N}$ & 138:04:37E & & $1 \mathrm{~min}$ & 0.014 & $\mathrm{UH}$ \\
\hline Saipan & $15: 13: 36 \mathrm{~N}$ & $145: 44: 31 \mathrm{E}$ & & $1 \mathrm{~min}$ & 0.083 & UH \\
\hline Chichijima & $27: 06 \mathrm{~N}$ & $142: 12 \mathrm{E}$ & & $15 \mathrm{~s}$ & 0.36 & JMA \\
\hline Hachijojima & $33: 07: 36 \mathrm{~N}$ & $139: 48: 28 \mathrm{E}$ & & $30 \mathrm{~s}$ & 0.094 & JCG \\
\hline Miyakejima & $34: 03 \mathrm{~N}$ & $139: 33 \mathrm{E}$ & & $15 \mathrm{~s}$ & 0.22 & JMA \\
\hline Kozushima & $34: 12: 18 \mathrm{~N}$ & 139:08:12E & & $30 \mathrm{~s}$ & 0.23 & JCG \\
\hline Soma & $37: 50 \mathrm{~N}$ & $140: 58 \mathrm{E}$ & & $30 \mathrm{~s}$ & 0.094 & GSI \\
\hline Katsuura & $35: 08 \mathrm{~N}$ & $140: 15 \mathrm{E}$ & & $30 \mathrm{~s}$ & 0.12 & GSI \\
\hline Mera & $34: 55 \mathrm{~N}$ & $139: 50 \mathrm{E}$ & & $15 \mathrm{~s}$ & 0.28 & JMA \\
\hline Boso 2 (OBTS) & $34: 44: 57 \mathrm{~N}$ & $140: 45: 29 \mathrm{E}$ & 2,098 & $1 \mathrm{~s}$ & 0.0087 & JMA \\
\hline Boso 3 (OBTS) & $34: 47: 58 \mathrm{~N}$ & $140: 30: 42 \mathrm{E}$ & 1,912 & $1 \mathrm{~s}$ & 0.012 & JMA \\
\hline Yokosuka & $35: 17: 05 \mathrm{~N}$ & 139:39:17E & & $30 \mathrm{~s}$ & 0.084 & JCG \\
\hline Aburatsubo & $35: 10 \mathrm{~N}$ & $139: 37 \mathrm{E}$ & & $30 \mathrm{~s}$ & 0.25 & GSI \\
\hline HPG1 (OBTS) & $35.00: 11 \mathrm{~N}$ & $139: 13: 29 \mathrm{E}$ & 1,176 & $1 \mathrm{~s}$ & 0.017 & JAMS \\
\hline Ito & $34: 53 \mathrm{~N}$ & $139: 08 \mathrm{E}$ & & $30 \mathrm{~s}$ & 0.043 & GSI \\
\hline Shimoda & $34: 41 \mathrm{~N}$ & $138: 58 \mathrm{E}$ & & $0.5 \mathrm{~s}$ & 0.30 & NAW \\
\hline Shimoda (WG) & $34: 38: 48 \mathrm{~N}$ & $138: 57: 11 \mathrm{E}$ & 51.1 & $0.5 \mathrm{~s}$ & 0.12 & NAW \\
\hline Irozaki & $34: 37 \mathrm{~N}$ & $138: 51 \mathrm{E}$ & & $15 \mathrm{~s}$ & 0.092 & JMA \\
\hline Tago & $34: 48 \mathrm{~N}$ & $138: 46 \mathrm{E}$ & & $30 \mathrm{~s}$ & 0.035 & GSI \\
\hline Uchiura & $35: 01 \mathrm{~N}$ & $138: 53 \mathrm{E}$ & & $15 \mathrm{~s}$ & 0.098 & JMA \\
\hline Shimizuminato & $35: 01 \mathrm{~N}$ & $138: 31 \mathrm{E}$ & & $15 \mathrm{~s}$ & 0.044 & JMA \\
\hline Yaizu & $34: 52 \mathrm{~N}$ & $138: 20 \mathrm{E}$ & & $30 \mathrm{~s}$ & 0.13 & GSI \\
\hline Omaezaki (WG) & $34: 37: 17 \mathrm{~N}$ & $138: 15: 33 \mathrm{E}$ & 22.8 & $0.5 \mathrm{~s}$ & 0.045 & NAW \\
\hline Tokai (OBTS) & $33: 45: 54 \mathrm{~N}$ & $137: 35: 23 \mathrm{E}$ & 2,202 & $1 \mathrm{~s}$ & 0.013 & JMA \\
\hline Tonankai 1 (OBTS) & $33: 39: 15 \mathrm{~N}$ & $136: 50: 26 \mathrm{E}$ & 2,050 & $1 \mathrm{~s}$ & 0.0079 & JMA \\
\hline Tonankai 2 (OBTS) & $33: 51: 28 \mathrm{~N}$ & $137: 21: 34 \mathrm{E}$ & 1,120 & $1 \mathrm{~s}$ & 0.013 & JMA \\
\hline Tonankai 3 (OBTS) & $34: 13: 02 \mathrm{~N}$ & $137: 41: 31 \mathrm{E}$ & 1,103 & $1 \mathrm{~s}$ & 0.0098 & JMA \\
\hline Maisaka & $34: 41 \mathrm{~N}$ & $137: 37 \mathrm{E}$ & & $15 \mathrm{~s}$ & 0.060 & JMA \\
\hline Owase & $34: 05 \mathrm{~N}$ & $136: 12 \mathrm{E}$ & & $15 \mathrm{~s}$ & 0.20 & JMA \\
\hline Kumano & $33: 56 \mathrm{~N}$ & $136: 10 \mathrm{E}$ & & $15 \mathrm{~s}$ & 0.32 & JMA \\
\hline Mie owase (GPS) & $33: 54: 08 \mathrm{~N}$ & $136: 15: 34 \mathrm{E}$ & 210 & $1 \mathrm{~s}$ & 0.049 & NAW \\
\hline Uragami & $33: 34 \mathrm{~N}$ & $135: 54 \mathrm{E}$ & & $15 \mathrm{~s}$ & 0.23 & JMA \\
\hline Kushimoto & $33: 29 \mathrm{~N}$ & $135: 46 \mathrm{E}$ & & $15 \mathrm{~s}$ & 0.43 & JMA \\
\hline Shionomisaki (WG) & $33: 25: 59 \mathrm{~N}$ & $135: 44: 50 \mathrm{E}$ & 54.7 & $0.5 \mathrm{~s}$ & 0.044 & NAW \\
\hline Shirahama & $33: 41 \mathrm{~N}$ & $135: 23 \mathrm{E}$ & & $15 \mathrm{~s}$ & 0.13 & JMA \\
\hline Gobo & $33: 51 \mathrm{~N}$ & $135: 10 \mathrm{E}$ & & $15 \mathrm{~s}$ & 0.23 & JMA \\
\hline Wakayama & $34: 13 \mathrm{~N}$ & $135: 09 \mathrm{E}$ & & $15 \mathrm{~s}$ & 0.067 & JMA \\
\hline Wakayama SW (GPS) & $33: 38: 32 \mathrm{~N}$ & $135: 09: 24 \mathrm{E}$ & 201 & $1 \mathrm{~s}$ & 0.033 & NAW \\
\hline Komatsushima & $34: 01 \mathrm{~N}$ & $134: 35 \mathrm{E}$ & & $15 \mathrm{~s}$ & 0.097 & JMA \\
\hline Awayuki & $33: 46 \mathrm{~N}$ & $134: 36 \mathrm{E}$ & & $15 \mathrm{~s}$ & 0.32 & JMA \\
\hline Murotomisaki & $33: 16 \mathrm{~N}$ & $134: 10 \mathrm{E}$ & & $15 \mathrm{~s}$ & 0.24 & JMA \\
\hline MPG1 (OBTS) & $32: 23: 27 \mathrm{~N}$ & $134: 28: 31 \mathrm{E}$ & 2,308 & $1 \mathrm{~s}$ & 0.0095 & JAMS \\
\hline MPG2 (OBTS) & $32: 38: 35 \mathrm{~N}$ & $134: 21: 53 \mathrm{E}$ & 1,507 & $1 \mathrm{~s}$ & 0.013 & JAMS \\
\hline Kochi & $33: 30 \mathrm{~N}$ & $133: 34 \mathrm{E}$ & & $15 \mathrm{~s}$ & 0.12 & JMA \\
\hline Kochi (WG) & $33: 28: 57 \mathrm{~N}$ & $133: 35: 13 \mathrm{E}$ & 24.1 & $0.5 \mathrm{~s}$ & 0.071 & NAW \\
\hline Susaki & $33: 23 \mathrm{~N}$ & $133: 18 \mathrm{E}$ & & $0.5 \mathrm{~s}$ & 0.22 & NAW \\
\hline Kure & $33: 20 \mathrm{~N}$ & $133: 15 \mathrm{E}$ & & $30 \mathrm{~s}$ & 0.16 & GSI \\
\hline Kamikawaguchi (WG) & $33: 01: 54 \mathrm{~N}$ & $133: 03: 29 \mathrm{E}$ & 27.9 & $0.5 \mathrm{~s}$ & 0.10 & NAW \\
\hline Tosashimizu & $32: 47 \mathrm{~N}$ & $132: 58 \mathrm{E}$ & & $15 \mathrm{~s}$ & 0.20 & JMA \\
\hline Kochi W (GPS) & $32: 37: 52 \mathrm{~N}$ & 133:09:21E & 309 & $1 \mathrm{~s}$ & 0.064 & NAW \\
\hline Hosojima & $32: 26 \mathrm{~N}$ & $131: 40 \mathrm{E}$ & & $30 \mathrm{~s}$ & 0.14 & GSI \\
\hline Hosojima (WG) & $32: 26: 36 \mathrm{~N}$ & $131: 43: 42 \mathrm{E}$ & 48.3 & $0.5 \mathrm{~s}$ & 0.040 & NAW \\
\hline
\end{tabular}


Table 1 continued

\begin{tabular}{|c|c|c|c|c|c|c|}
\hline Station* & Latitude (deg:min:s) & Longitude (deg:min:s) & Water depth (m) & Record sampling & $\operatorname{MTH}(\mathrm{m})^{* *}$ & Agencies*** \\
\hline Aburatsu & $31: 35 \mathrm{~N}$ & $131: 25 \mathrm{E}$ & & $15 \mathrm{~s}$ & 0.21 & JMA \\
\hline Shibushi & $31: 29 \mathrm{~N}$ & 131:07E & & $0.5 \mathrm{~s}$ & 0.16 & NAW \\
\hline Odomari & $31: 01: 12 \mathrm{~N}$ & $130: 41: 29 \mathrm{E}$ & & $30 \mathrm{~s}$ & 0.26 & JCG \\
\hline Nishinoomote & $30: 43: 53 \mathrm{~N}$ & 130:59:40E & & $30 \mathrm{~s}$ & 0.21 & JCG \\
\hline Tanegashima & $30: 28 \mathrm{~N}$ & $130: 58 \mathrm{E}$ & & $15 \mathrm{~s}$ & 0.33 & JMA \\
\hline Naze (WG) & $28: 27: 07 \mathrm{~N}$ & $129: 31: 18 \mathrm{E}$ & 54.6 & $0.5 \mathrm{~s}$ & 0.031 & NAW \\
\hline Amami & $28: 19 \mathrm{~N}$ & $129: 32 \mathrm{E}$ & & $15 \mathrm{~s}$ & 0.24 & JMA \\
\hline Nakagusu & $26: 20 \mathrm{~N}$ & $127: 50 \mathrm{E}$ & & $0.5 \mathrm{~s}$ & 0.11 & NAW \\
\hline Nakagusu (WG) & $26: 14: 32 \mathrm{~N}$ & $127: 57: 55 \mathrm{E}$ & 39.6 & $0.5 \mathrm{~s}$ & 0.052 & NAW \\
\hline Okinawa & $26: 11 \mathrm{~N}$ & $127: 49 \mathrm{E}$ & & $30 \mathrm{~s}$ & 0.10 & GSI \\
\hline Naha & $26: 13 \mathrm{~N}$ & $127: 40 \mathrm{E}$ & & $15 \mathrm{~s}$ & 0.085 & JMA \\
\hline Naha (WG) & $26: 15: 28 \mathrm{~N}$ & $127: 38: 52 \mathrm{E}$ & 51.0 & $0.5 \mathrm{~s}$ & 0.033 & NAW \\
\hline Taira & $24: 49 \mathrm{~N}$ & $125: 17 \mathrm{E}$ & & $0.5 \mathrm{~s}$ & 0.11 & NAW \\
\hline Ishigaki & $24: 20 \mathrm{~N}$ & $124: 10 \mathrm{E}$ & & $15 \mathrm{~s}$ & 0.080 & JMA \\
\hline Ishigakioki (WG) & $24: 21: 55 \mathrm{~N}$ & 124:06:10E & 34.8 & $0.5 \mathrm{~s}$ & 0.036 & NAW \\
\hline Yonaguni & $24: 27 \mathrm{~N}$ & $122: 57 \mathrm{E}$ & & $15 \mathrm{~s}$ & 0.037 & JMA \\
\hline Minamidaitojima & $25: 52 \mathrm{~N}$ & 131:14E & & $15 \mathrm{~s}$ & 0.039 & JMA \\
\hline
\end{tabular}

Values written in bold are from JMA (2009), the others are read in this study

$W G$ wave gauge, GPS GPS buoy, OBTS ocean bottom tsunami sensor, JMA Japan Meteorological Agency, UH University of Hawaii, Sea Level Center, BAKO National Coordination Agency for Surveys and Mapping, Indonesia (BAKOSURTANAL), JCG Japan coastal guard, GSI Geographical Survey Institute, NAW Nationwide Ocean Wave information network for Ports and HArbourS (NOWPHAS), JAMS Japan Agency for Marine-Earth Science and Technology (JAMSTEC)

* Station names with the sensor types in parentheses. Tide gauges are listed without parentheses

** Maximum tsunami height (positive value of zero-to-peak of the observed tsunami waveform)

*** Agencies or networks which are responsible for the tsunami waveforms data

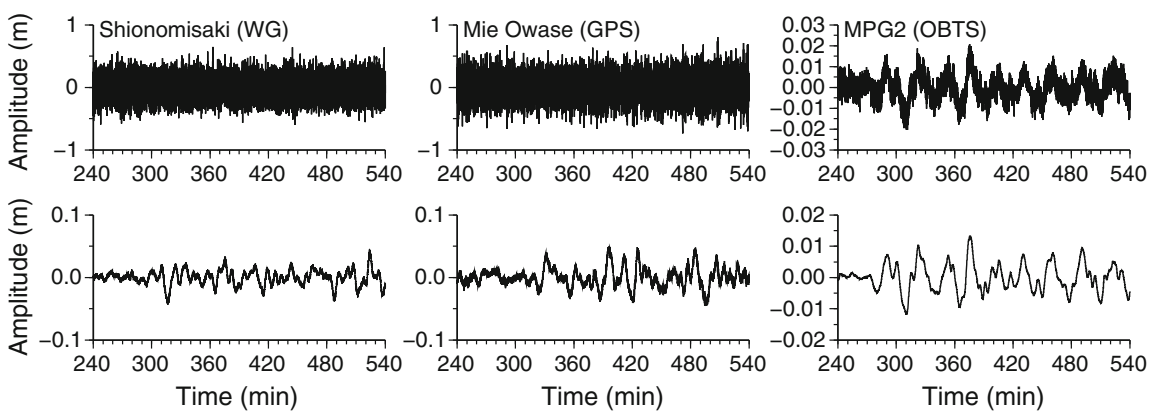

Figure 5

Tsunamis recorded on near-shore wave gauge (left), offshore GPS buoy (middle) and ocean bottom tsunami sensor (right). At each station (the locations are shown in Fig. 4a) the upper trace shows the de-tided records including short-period components, and the bottom traces are the tsunami signals by filtering out the short-period components

$5 \mathrm{~cm}$ at the GPS buoys, and up to $1.5 \mathrm{~cm}$ at the OBTS, respectively. These differences of the tsunami amplitude are basically due to the differences in water depth at the observation point. The tide gauges are installed along coastal areas at depths of a few to several meters, wave gauges at depths of about 10 to
$50 \mathrm{~m}$, GPS buoys at depths of about $200 \mathrm{~m}$, and OBTS at depths of about $1,000-4,000 \mathrm{~m}$. The tsunami with maximum amplitude of $36 \mathrm{~cm}$ was observed at Chichijima located on Izu-Bonin ridge, which is comparable to that observed at Manokwari, the nearest tide gauge to the sources. 


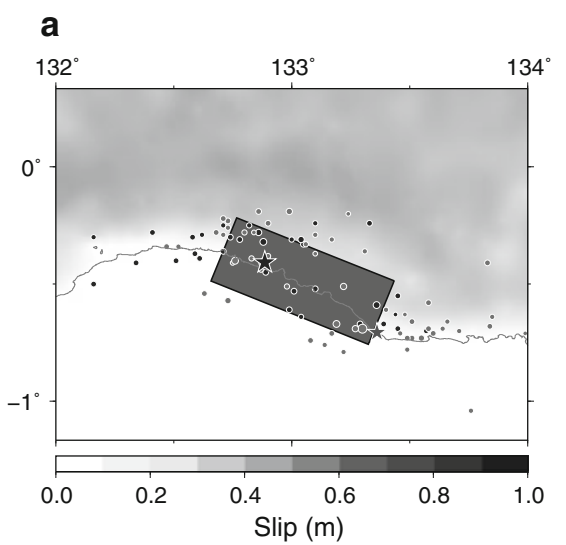

\section{b}

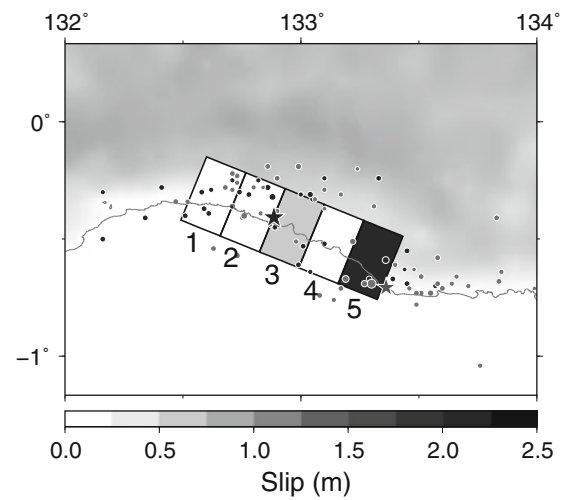

Figure 6

Slip distributions estimated by tsunami waveform inversions adopting different fault models (a single fault, b five subfaults) with subfault numbers. Black star shows the mainshock epicenter. Circles in black indicate aftershocks within about $3 \mathrm{~h}$ after the mainshock (before the second event). The second event and following aftershocks within 1 day after that event are also shown in gray symbols

\section{Tsunami Modeling}

\subsection{Bathymetry Data}

Since phase velocities of shallow-water (tsunami) waves depend on water depth, accurate bathymetric data are essential for tsunami numerical computations. For the global ocean, a gridded bathymetry dataset is available from GEBCO (British Oceanographic Data Centre, 1997). The GEBCO data was newly updated with 30 arc-second grid resolution (GEBCO_08). We use this bathymetry data for calculating tsunami waveforms or Green functions.

\subsection{Fault Models}

We first assume a single fault for the first event and estimate the average slip on the fault. Then, in order to estimate the extent of the tsunami source and its slip distribution, we divide the tsunami source into five subfaults to cover the area of aftershocks that occurred during $3 \mathrm{~h}$ after the first event but before the second event (Fig. 6). A fault model for the second event is not considered, because the tsunami from the second event overlapped with the later phases of the first event's tsunami, which made it difficult to distinguish the arrival of the second event's tsunami from the observed records.

We perform two sets of inversion to estimate the tsunami source using the single fault model and five-
Table 2

Slip distributions estimated by tsunami waveform inversions with different fault models

\begin{tabular}{lllll}
\hline No. & Latitude $\left({ }^{\circ} \mathrm{S}\right)$ & Longitude $\left({ }^{\circ} \mathrm{E}\right)$ & \multicolumn{2}{l}{ Slip and error $(\mathrm{m})$} \\
\cline { 3 - 5 } & & Single fault & Five subfaults \\
\hline 1 & 0.15 & 132.6 & - & $0.00 \pm 0.14$ \\
2 & 0.21777 & 132.76661 & $0.64 \pm 0.32$ & $0.00 \pm 0.00$ \\
3 & 0.28553 & 132.93323 & & $0.70 \pm 0.34$ \\
4 & 0.35330 & 133.09984 & & $0.00 \pm 0.17$ \\
5 & 0.42106 & 133.26597 & & $2.07 \pm 1.10$ \\
\hline
\end{tabular}

Location (latitude and longitude) indicates the northwest corner of each fault or subfault

subfault model. The size of the fault is $80 \times 40 \mathrm{~km}$ for the single fault model. For the five subfault model, each subfault is $20 \times 40 \mathrm{~km}$ (Fig. 6 and Table 2). The focal mechanism of strike $112^{\circ}$, dip $36^{\circ}$, slip angle $77^{\circ}$, from the USGS CMT solution of the first event, and the top depths of $10 \mathrm{~km}$, are adopted for all the fault models. We assume an instantaneous rupture for the two fault models, because the tsunami propagation velocity is $0.1 \mathrm{~km} /$ $\mathrm{s}$ for the water depth of $1,000 \mathrm{~m}$, much smaller than the typical rupture velocity of a few $\mathrm{km} / \mathrm{s}$. The epicenter is located between subfaults 2 and 3 .

\subsection{Finite-Difference Computation}

In order to calculate tsunami propagation from each fault to the stations, the linear shallow-water, or 
long-wave, equations were numerically solved by using a finite-difference method (SATAKe, 1995). Details of the governing equations without Coriolis force are described in FujII and Satake (2007). The computation area extends from $120^{\circ} \mathrm{E}$ to $155^{\circ} \mathrm{E}$ and $5^{\circ} \mathrm{S}$ to $45^{\circ} \mathrm{N}$ (rectangular area in Fig. 3a. The bathymetric grid interval is uniformly $30^{\prime \prime}$ (30 arc-seconds, about $0.9 \mathrm{~km}$ ), hence there are 4,200 $\times 6,000$ grid points along the longitude and latitude directions, respectively. We set a minimum water depth on the coasts to $2 \mathrm{~m}$. Because the observed tsunami heights of the West Papua tsunami were mostly up to a few tens of centimeters at the tide gauges, the small amplitude assumption in linear shallow-water longwave equations is valid. We made the computations of $9 \mathrm{~h}$ for tsunami propagation. A time step of $1 \mathrm{~s}$ is used to satisfy the stability condition for the finitedifference method.

As an initial condition for the tsunami numerical computation, static deformation of the seafloor is calculated for a rectangular fault model (ОкADA, 1985) and used assuming that the initial water height distribution is the same as that of seafloor. We also consider the effects of coseismic horizontal displacement in regions of steep bathymetric slope (TANIOKA and Satake, 1996). We assumed a constant rise time (or slip duration) of $30 \mathrm{~s}$ for the single fault model and each subfault. Waveforms at the observed stations were computed and used as Green functions for the inversion.

\subsection{Tsunami Waveform Inversions}

We used the non-negative least square method (LAWSON and HANSON, 1974) and delete-half jackknife method (TichelaAR and RufF, 1989) to estimate slips and errors, respectively. The observed tsunami waveforms were resampled at $1 \mathrm{~min}$ intervals, hence synthetic waveforms are also computed at $1 \mathrm{~min}$ interval. We used the first cycles of the tsunami waveforms for the inversions, because the limited resolution of bathymetry data near coastal tide gauges and near-shore wave gauges may prevent accurate modeling of later phases such as reflected waves. The total number of data points used for the inversions is 641. We weight the OBTS data ten times, GPS buoy data five times, and wave gauge data three times greater than the other tide gauge data, because the amplitudes of near-shore or offshore records are smaller, by an order of magnitude as described in Sect.2, than those of tide gauge records.

\section{Results and Discussions}

The inversion results are shown in Table 2 and Fig. 6. The estimated slip on the single fault model (Fig. 6a) is $0.64 \mathrm{~m}$, which yields a seismic moment of $1.02 \times 10^{20} \mathrm{Nm}\left(M_{\mathrm{w}}=7.3\right)$ assuming a rigidity of $5.0 \times 10^{10} \mathrm{~N} / \mathrm{m}^{2}$. For the five-subfault model (Fig. 6b), a moderate slip of $0.70 \mathrm{~m}$ was estimated near the epicenter (subfault 3) and a large slip of $2.07 \mathrm{~m}$ was located on the eastern end of the source (subfault 5). The amount of largest slips at the eastern end of the source region in the five-subfault models may not be well resolved because of the large error $(1.10 \mathrm{~m}$; see Table 2). The total seismic moment is calculated as $1.11 \times 10^{20} \mathrm{Nm}\left(M_{\mathrm{w}}=7.3\right)$ for the five-subfault model, assuming the same rigidities of $5.0 \times 10^{10} \mathrm{~N} / \mathrm{m}^{2}$ for all the subfaults. Regardless of the fault models, the estimated moment magnitude is smaller than that inferred from seismic data (cf. $M_{\mathrm{w}}=7.6$ from USGS CMT solution). Before the inversions, we performed a forward modeling referring the source model of $M_{\mathrm{w}}=7.6$ and found that the first-wave amplitudes of synthetic waveforms at some stations of OBTS (off Tokai, Tonankai and Shikoku) were overestimated for the observed amplitudes. Since the Green functions of such OBTS installed in deep sea, which were used for the inversions, must be calculated more accurately than the ones of tide gauges or wave gauges located near coasts, the moment magnitude of 7.6 might be slightly overestimated for the tsunami generation. The source process of the 2009 West Papua earthquake has been inferred from teleseismic body waves by HAYES (2009) and PoiAta et al. (2010). Their results show a single asperity around the epicenter. The large slip on subfault 3 in the five-subfault model may correspond to their single asperities.

Comparison of the observed tsunami waveforms and the synthetic ones from the single fault model is shown in Fig. 7. The calculated tsunami waveforms from the five-subfault model are not shown, because the differences in synthetic waveforms from the two 


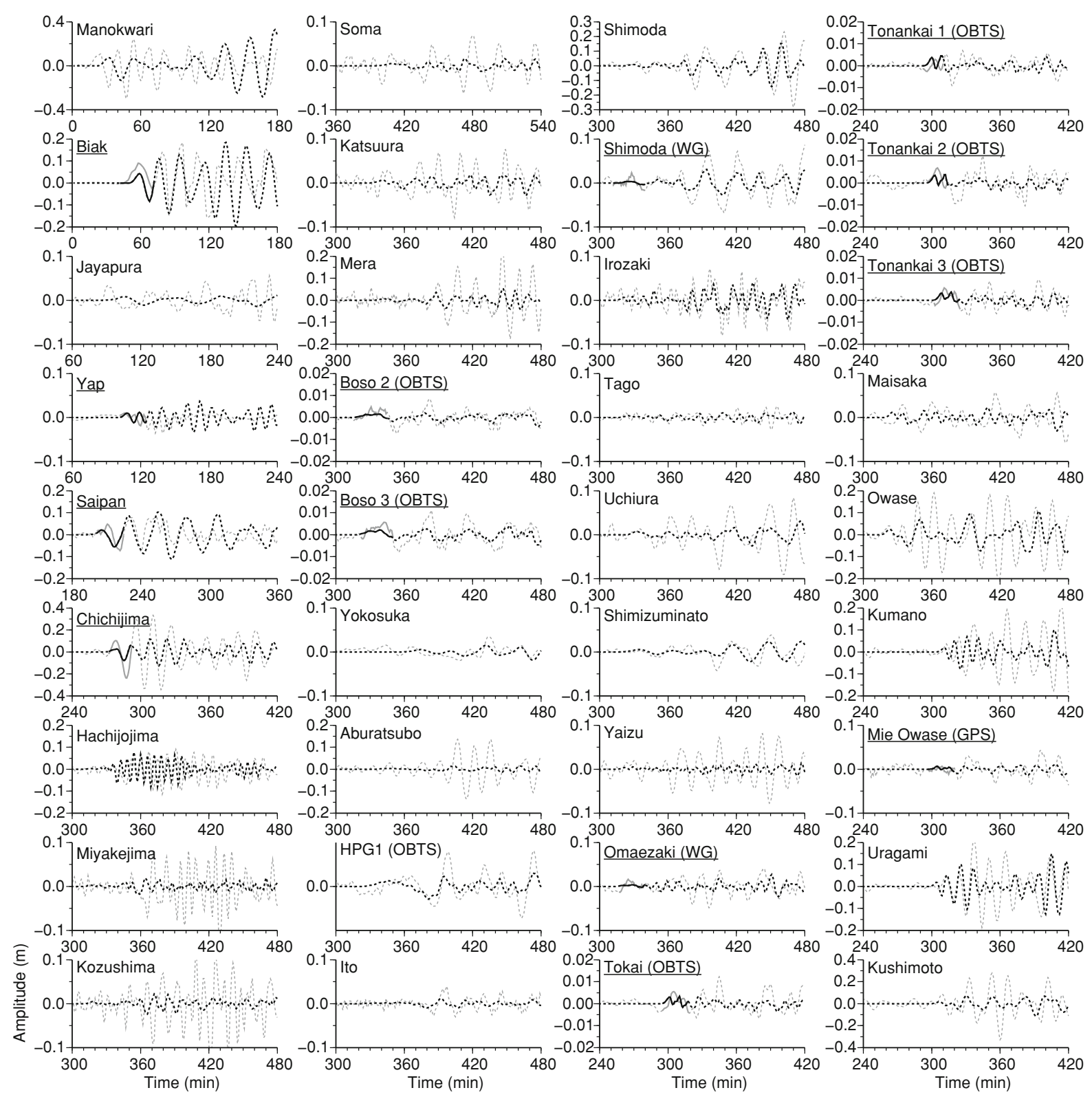

Figure 7

a Comparisons of the observed (gray lines) and synthetic (black lines) tsunami waveforms computed from the estimated slip by adopting the single model. Time ranges shown by solid curves are used for the inversions; the dashed parts are not used for the inversions, but shown for comparison. Out of 36 waveforms shown here, we used parts of 13 records (underlined stations) for the inversions. b (cont'd) Out of 36 waveforms shown here, we used parts of 13 records (underlined stations) for the inversions. (Submitted January 3, 2010, Revised June 15, 2010, Accepted July 1, 2010)

fault models are much smaller than the differences between the observed and synthetic waveforms. We used most of the observed tsunami waveforms at wave gauges, GPS buoys, and OBTS around Japan for the inversions. On the other hand, we used the observed tsunami waveforms at five tide gauges on the small islands (Biak, Yap, Saipan, Chichijima, Minamidaitojima) which are located on the tsunami's way from the source to the offshore or near-shore stations of the Japanese main islands. Some stations' data were not used for the inversions, because the first arrivals of the observed waveforms do not match the 


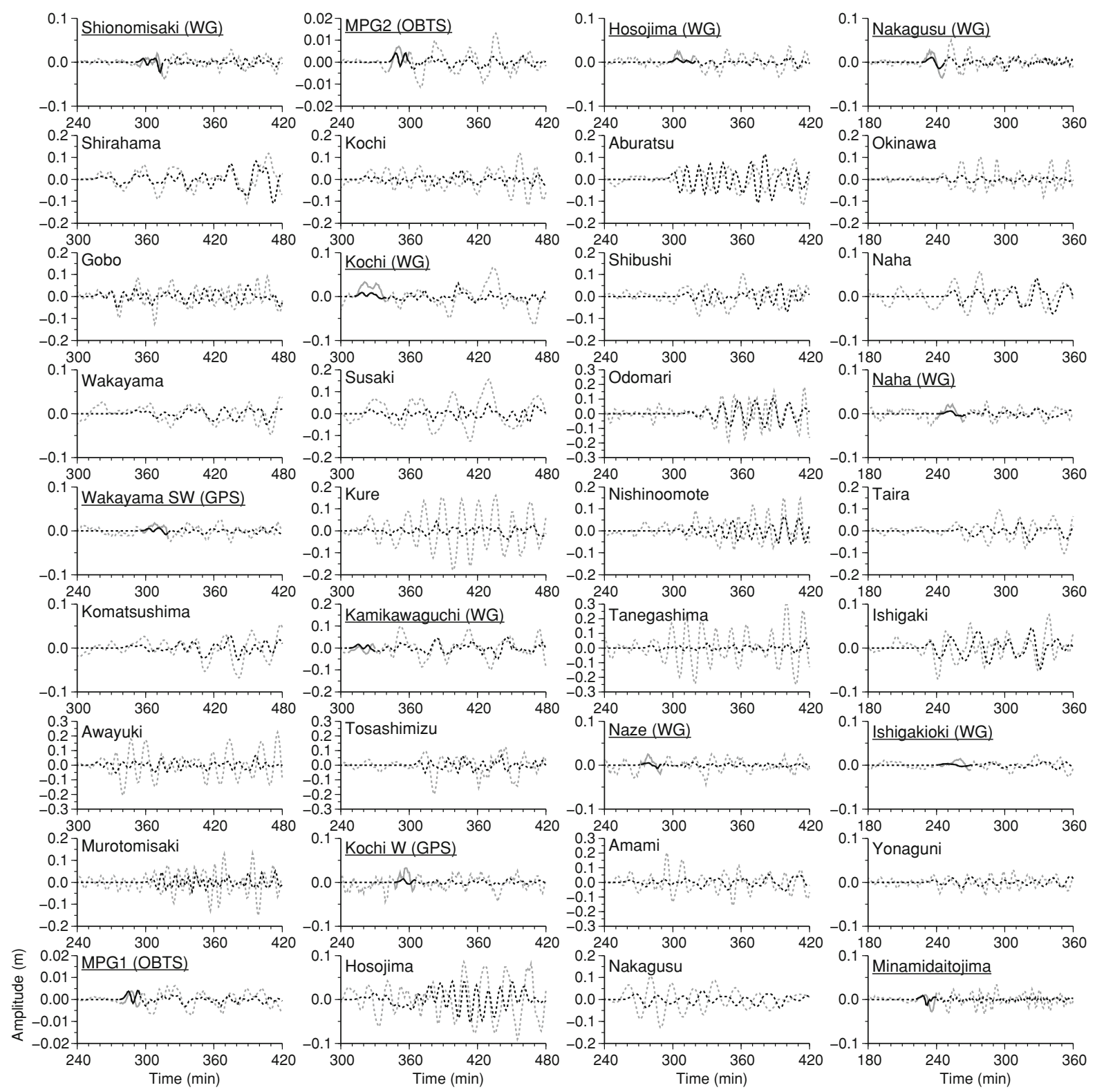

Figure 7

continued

synthetic ones (e.g. Manokwari, Jayapura, HPG1 (OBTS)), although the tide gauges are located close to the source. The synthetic waveforms generally agree with the observed phases at most stations, however, the calculated tsunami amplitudes are consistently underestimated. At some stations (e.g. Biak, Saipan, Shimoda (WG)), the synthetic waveforms are well reproduced not only for the first cycles of tsunami waveforms (inversion time windows) but also for the later phases which were not used in the inversions. It is difficult to judge which of the single fault and five-subfault model is the best model, because the differences of the synthetic waveforms among the both fault models are very 
small. This may indicate the limitation due to the poor station coverage to resolve the extent of the tsunami source; in this case we mainly used far field data located in the direction perpendicular to the fault strike.

\section{Conclusions}

The tsunamis generated by the January 2009 West Papua, Indonesia earthquakes were recorded not only at many coastal tide gauges located in and around the Pacific Ocean but also at near-shore wave gauges, off-shore GPS buoys and OBTS off the Japanese coasts. Using the observed tsunami waveforms, we modeled the tsunami from the first event to estimate the tsunami source and found that the tsunami data observed at tide gauges, wave gauges, GPS buoys and OBTS were well reproduced. The recently updated bathymetry data of GEBCO_08, 30 arc-second grid data was used in the tsunami simulations. The average slip of $0.64 \mathrm{~m}$ was estimated on the single fault of $80 \times 40 \mathrm{~km}$. The calculated seismic moment is $1.01 \times 10^{20} \mathrm{Nm}$ $\left(M_{\mathrm{w}}=7.3\right)$, slightly less than the magnitude inferred from seismic data $\left(M_{\mathrm{w}}=7.7\right)$.

\section{Acknowledgments}

We thank the National Coordination Agency for Surveys and Mapping (BAKOSURTANAL), Japan Coastal Guard (JCG), Geographical Survey Institute (GSI), and West Coast/Alaska Tsunami Warning Center (WCATWC) for providing us tide gauge data. We also thank Ports and Harbors Bureau (PHB) under the Ministry of Land, Infrastructure, Transport and Tourism (MLIT) and Port and Airport Research Institute (PARI) for providing us with tide gauge, wave gauge and GPS buoy data. The data of ocean bottom tsunami sensors of the Japan Agency for Marine-Earth Science and Technology (JAMSTEC) were downloaded from their web site. We thank Efim Pelinovsky and an anonymous reviewer for their valuable comments which have improved our manuscript. Most of the figures were generated using the Generic Mapping Tools (Wessel And SMith, 1998).
This research was partially supported by Grants-inAid for Scientific Research (B) (No. 21310113), Ministry of Education, Culture, Sports, Science and Technology (MEXT), and Science and Technology Research Partnership for Sustainable Development (SATREPS) from Japan Science and Technology Agency (JST), Japan International Cooperation Agency (JICA), State Ministry of Research and Technology of Indonesia (RISTEK) and Indonesian Institute of Science (LIPI).

Open Access This article is distributed under the terms of the Creative Commons Attribution Noncommercial License which permits any noncommercial use, distribution, and reproduction in any medium, provided the original author(s) and source are credited.

\section{REFERENCES}

British Oceanographic Data Centre (1997). The centenary edition of the GEBCO digital atlas (CD-ROM).

FujII, Y., and Satake, K. (2007). Tsunami source of the 2004 Sumatra-Andaman earthquake inferred from tide gauge and satellite data, Bull. Seism. Soc. Am., 97, S192-S207.

Hayes, G. (2009). Preliminary result of the Jan 3, $2009 M_{\mathrm{w}}$ 7.6 Papua Earthquake, http://earthquake.usgs.gov/eqcenter/ eqinthenews/2009/us2009bjbn/finite_fault.php.

JMA (2002). Monthly report on earthquakes and volcanoes in Japan, September, 2002 (in Japanese).

JMA (2009). Monthly report on earthquakes and volcanoes in Japan, January, 2009 (in Japanese).

Lawson, C. L., and Hanson, R. J. (1974). Solving least squares problems, 340 pp., Prentice-Hall, Inc., Englewood Cliffs, NJ.

Muhari, A., Kisman, M., Wanma, B., and Wanma, F. (2009). The 'Doublet' earthquake at Papua, Indonesia January 3rd, 2009, Survey Report and Preliminary Model Analysis, Sub Directorate for Coastal Disaster Mitigation Ministry of Marine Affairs and Fisheries.

OкADA, Y. (1985). Surface deformation due to shear and tensile faults in a half-space, Bull. Seismol. Soc. Am., 75, 1135-1154.

Окац, Е. А. (1999). Historical seismicity and seismotectonic context of the great 1979 Yapen and 1996 Biak, Irian Jaya earthquakes, Pure. Appl. Geophys., 154, 633-675.

Poiata, N., Koketsu, K., and Miyake, H. (2010). Source processes of the 2009 Irian Jaya, Indonesia, earthquake doublet, Earth Planets Space, 62, 475-481.

SAtAKE, K. (1995). Linear and nonlinear computations of the 1992 Nicaragua earthquake tsunami, Pure. Appl. Geophys., 144, 455-470.

Satake, K., and Kanamori, H. (1991). Abnormal tsunamis caused by the June 13, 1984, Torishima, Japan, earthquake, J. Geophys. Res. Solid Earth, 96, 19933-19939.

Satake, K., Yoshida, Y., and Abe, K. (1992). Tsunami from the Mariana earthquake of April 5, 1990-Its abnormal propagation and implications for tsunami potential from outer-rise earthquakes, Geophys. Res. Lett., 19, 301-304. 
Tanioka, Y., and Satake, K. (1996). Tsunami generation by horizontal displacement of ocean bottom, Geophys. Res. Lett., 23, 861-864.

TichelaAr, B. W., and RufF, L. J. (1989). How good are our best models? Jackknifing, bootstrapping, and earthquake depth, Eos Trans. AGU, 70, 593, 605-606.
Wessel, P., and Smith, W. H. F. (1998). New, improved version of the generic mapping tools released, EOS Trans. AGU, 79, 579.

(Received January 3, 2010, revised June 15, 2010, accepted July 1, 2010, Published online December 14, 2010) 